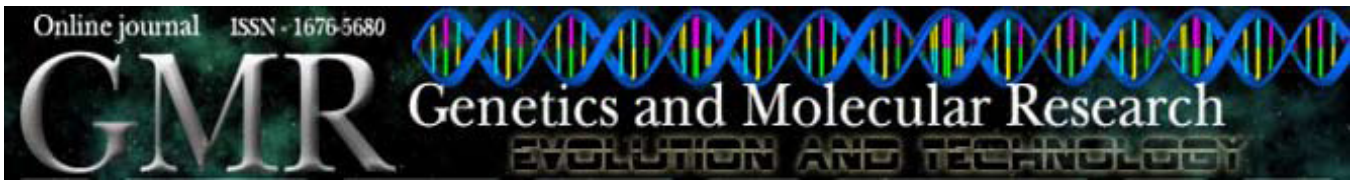

\title{
Survival of the thriftiest: restricted nurture reveals the thrifty nature of a growth gene in Bos indicus
}

\author{
S.U. Dani ${ }^{1}$, M.A.C. Dani ${ }^{1,2}$, I.L. Freire ${ }^{3}$, S.P. Gouvea ${ }^{4}$, F.B. Knackfuss ${ }^{1}$, \\ F.P. Lima ${ }^{5}$, M.E.Z. Mercadante ${ }^{5}$, E. Monteiro' ${ }^{1}$, S.M.G. Paggiaro ${ }^{4}$, \\ A.G. Razook ${ }^{5}$ and H.C. Yehia ${ }^{1,3}$ \\ ${ }^{1}$ Excegen Genética S.A., Acangau Valley, Paracatu, MG, Brasil \\ ${ }^{2}$ Coarana Biotecnologia Ltda., Acangau Valley, Paracatu, MG, Brasil \\ ${ }^{3}$ Universidade Federal de Minas Gerais, Belo Horizonte, MG, Brasil \\ ${ }^{4}$ Genon Genética Ltda., Ribeirão Preto, SP, Brasil \\ ${ }^{5}$ Instituto de Zootecnia/APTA, Sertãozinho, SP, Brasil \\ Corresponding author: S.U. Dani \\ E-mail:srgdani@gmail.com
}

Genet. Mol. Res. 9 (2): 1032-1044 (2010)

Received February 20, 2010

Accepted March 19, 2010

Published June 1, 2010

DOI 10.4238/vol9-2gmr844

\begin{abstract}
Growth hormone (GH) is a part of the somatotropic axis that controls metabolism, growth, development and aging in a wide range of animals. Mutations that reduce GH signaling have been associated with extended life spans and increased longevity in ways similar to what is observed in dietary restriction (DR) models. However, the mechanism by which DR works is not well understood. Here, we show that DR works as a factor in the evolution of the genetic make-up of domestic cattle. In a series of 6864 bovines of seven Bos indicus and tropically adapted Bos taurus breeds, the frequency of a short, wildtype allele of the promoter region of the bovine $G H$ gene, $G 1$ allele, varied from 2.7 to $17.7 \%$. The frequency of the long, domestic $G 2$ allele increased from 88 to $95 \%$ along 20 calf crops of commercial Bos indicus cattle of the Nelore breed undergoing selection for increasing
\end{abstract}


post-weaning weight gain with ad libitum nutrient intake. Under DR, however, the $G 1$ allele sustained growth better than the $G 2$ allele, as observed in a series of feeding tests. The $G 2$ allele was even detrimental or abiotropic, as it caused rapid body decay under DR. We observed a reflection symmetry of $G H$ allele substitution effects on body weight under different dietary schemes. The $G 2$ allele is featured as the "demanding allele", because it is optimally fitted to ad libitum nutrient intake. The $G 1$ allele is featured as the "thrifty allele" because it is optimally fitted to DR. Our results show that dietary regimens need not extend lifespan or increase longevity in the sense of age-specific fitness. Instead, adaptation to any particular dietary regimen is just as much a consequence of selection as its cause; dietary regimens work as do any selection force, optimizing genotypic fitness to nutritional conditions.

Key words: Growth hormone; Bos indicus; Dietary restriction; Thrifty gene; Longevity; Marker-assisted selection

\section{INTRODUCTION}

Growth hormone (GH), as part of the somatotropic axis, controls metabolism, growth, development, and aging in a wide range of animals (Berryman et al., 2008). Mutations that reduce GH signaling have been associated with extended life spans and increased longevity in ways similar to what is observed in dietary restriction (DR) models (Shimokawa et al., 2003; Zha et al., 2008). However, the mechanisms by which DR works are not well understood.

In bovines, it has been shown that the somatotropic axis is functionally coordinated by nutrient intake and GH (Smith et al., 2002; Butler et al., 2003; Radcliff et al., 2006). Associations of $G H$ gene polymorphisms and bovine growth and carcass traits have been reported (Schlee et al., 1994; Lee et al., 1996; Grochowska et al., 2001; Sorensen et al., 2002; Paz, 2002; Ge et al., 2003; Katoh et al., 2008). However, these studies were performed on Bos taurus populations under ad libitum feeding conditions.

Biallelic $G 1 / G 2$ polymorphism is characterized by the presence of one $(G 1)$ or two (G2) AAG trinucleotides in tandem, 9 bp upstream from the TATA-box transcriptional control site in the promoter region of the bovine GH gene ( $p G H$ ) (Gordon et al., 1983; Rodrigues et al., 1998, 1999). The long G2 allele was originally described in Bos taurus cattle (Gordon et al., 1983), while the short $G 1$ allele was observed in water buffaloes, Bubalus bubalis, and also in Bos indicus and some tropically adapted Bos taurus breeds (Rodrigues et al., 1998, 1999). Since molecular phylogenetics has shown that Bos and Bubalus shared the same ancestor some 5-8 million years ago (Ritz et al., 2000; MacEachern et al., 2009), we assume that the $G 1$ allele is the ancient wild-type form, whereas the $G 2$ allele is the mutated, domestic form.

To understand the effects of each $p G H$ allele on bovine growth and adaptability in domestication, we genotyped a large series of 6864 bovines of seven Bos indicus or tropically adapted Bos taurus breeds reared in Brazil. Feeding tests were performed in four different locations in Brazil characterized by varying degrees of nutrient intake, from ad libitum feeding in feedlots and supplemented pasture to varying degrees of DR, under exclusive pasture diets. 


\section{MATERIAL AND METHODS}

Animals were genotyped by polymerase chain reaction (PCR) and PCR-RFLP (restriction fragment length polymorphism), followed by gel electrophoresis and fragment analysis. Preliminary screening was performed in the Excegen database to establish genotype frequencies in the different cattle breeds. Feeding tests were performed with animals of the Nelore breed in four different locations in Brazil that are characterized by varying degrees of nutrient intake, from ad libitum feeding in feedlots and supplemented pasture in Sertãozinho and São Carlos, São Paulo State, respectively, to varying degrees of DR under exclusive pasture diets in Sertãozinho, Jaraguari and Paracatu. Animals were weighed at regular intervals up to age 570 days, according to feeding test protocols at each location. Growth traits and the contrasts between genotypes were analyzed by least squares and maximum likelihood methods, a mixed model to separate selection response from genotype effects, and Cohen's d effect size measure, with differences checked for statistical significance by the Komolgorov-Smirnov test. Detailed descriptions of material and methods are provided next and in Table 1.

\section{Samples and genotyping}

Either nasal swabs conserved in ethanol or about 40 hair follicles from the tail of each animal were collected in the field. DNA from $40 \mu \mathrm{L}$ of nasal swab was extracted using the "DNA IQ System" (Promega, USA), according to manufacturer instructions. DNA extraction from hair follicles followed a standard phenol-chloroform extraction method. Extracted DNA was dissolved in deionized water to the final working concentration $(50 \mathrm{ng} / \mu \mathrm{L})$. PCR for $p G H$ genotyping was carried out with primers 5'-TGGCAGTGGAGACGGGATGATG-3' (forward primer, FAM-labeled) and 5'-CCTGCTGGGCCATTTTTATACCCTGG-3' (reverse primer). The PCR mixture included: $2 \mathrm{mM} \mathrm{MgCl}, 0.375 \mathrm{mM}$ each dNTP, 1 pmol each of forward and reverse primers, 1 unit $\operatorname{GenoTaq}^{\circledR}(5 \mathrm{U} / \mu \mathrm{L}$, Genon Ltda., Brazil) and 50 ng DNA template, in a $20-\mu \mathrm{L}$ total reaction volume overlayed with mineral oil. PCR was carried out in a Mastercycler PCR thermocycler (Eppendorf, Germany), with the following profile: hot start at $94^{\circ} \mathrm{C}$, $10 \mathrm{~min} ; 35$ cycles of $94^{\circ} \mathrm{C}$ for $1 \mathrm{~min}, 58^{\circ} \mathrm{C}$ for $1 \mathrm{~min}$ and $72^{\circ} \mathrm{C}$ for $1 \mathrm{~min}$; final extension at $72^{\circ} \mathrm{C}$ for $4 \mathrm{~min}$, then a post-reaction at $4{ }^{\circ} \mathrm{C}$. $p G H$ PCR products of $193 \mathrm{bp}$ (G1 allele) or 196 bp (G2 allele) were separated and analyzed by polyacrylamide gel electrophoresis (PAGE) in a MegaBACE 1000 capillary sequencer (GE Healthcare Life Sciences, USA). Electropherograms were analyzed using the Fragment Profiler software and the results were deposited in our data bank for further statistical analyses.

PCR-RFLP genotyping of exon-5 of $G H$, to which the $G H$ gene $L 127 \mathrm{~V}$ polymorphism has been ascribed (Lucy et al., 1991), was performed according to Schlee et al. (1994) in a subset of 85 Nelore bulls taken at random out of our series of experimental animals, encompassing all three $G 1, G 2$ genotypes. This was meant as a screening to rule out any confounding effects of the $L 127 \mathrm{~V}$ variant site on production traits (Lee et al., 1996; Grochowska et al., 2001; Paz, 2002; Sorensen et al., 2002; Ge et al., 2003). PCR-RFLP AluI (Gibco BRL, $10 \mathrm{U} / \mu \mathrm{L}$ ) digests were separated by PAGE, followed by silver staining, as described by Sanguinetti et al. (1994). Any possible confounding effects of the $G H$ gene $L 127 \mathrm{~V}$ variant site on growth traits were ruled out because all experimental herds were monomorphic $(L L)$. The fixation of the $L L$ genotype in our herds confirms previous reports on $L$ allele fixation in the Brazilian Nelore 
population (Rosa, 1997) and the Brahman breed (DeNise, 1996). Absence of the $V$ allele in the zebu population in Brazil could be explained by the small number of animals that gave origin to the Brazilian herd and by the very low frequency of this allele (Mitra et al., 1995).

\section{Field conditions, feeding tests}

Experimental conditions ranged from pasture feeding (Sertãozinho, Jaraguari and Paracatu) to supplemented pasture feeding (São Carlos), to feedlot feeding (Sertãozinho). Pasture quality, as assessed by availability of green roughage during the feeding tests, decreased from irrigated pasture on quartzarenic neosol (Perdizes Farm, Jaraguari, MS, 20²2’29.78’S, $54^{\circ} 18^{\prime} 52.66^{\prime} \mathrm{W}$ ), to non-irrigated pasture on basalt-derived, dusky-red latosol (Sertãozinho Experimental Station, Sertãozinho, SP, $21^{\circ} 9^{\prime} 38.73^{\prime}$ 'S, $\left.48^{\circ} 5^{\prime} 28.85^{\prime \prime} \mathrm{W}\right)$, to non-irrigated pasture on red-yellow quartzarenic latosol (Varanda Farm, São Carlos, SP, 21 ${ }^{\circ} 58^{\prime} 32.80^{\prime \prime}$, $\left.47^{\circ} 45^{\prime} 45.57^{\prime} \mathrm{W}\right)$, to non-irrigated pasture on a more oxidic, "chapada" type litholic neosol

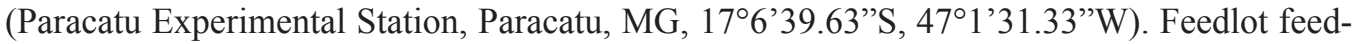
ing was our experimental model of ad libitum feeding, whereas pasture feeding constituted a model of varying degrees of DR. Animals were weighed at regular intervals from birth to 570 days of age, according to the feeding test protocols at each location (Table 1).

\begin{tabular}{|c|c|c|c|c|c|c|}
\hline & $\begin{array}{l}\text { Sertãozinho } \\
\text { (Feedlot) }\end{array}$ & $\begin{array}{c}\text { São Carlos } \\
\text { (Supplemented pasture) }\end{array}$ & $\begin{array}{c}\text { Jaraguari } \\
\text { (Irrigated pasture) }\end{array}$ & $\begin{array}{l}\text { Sertãozinho } \\
\text { (Pasture) }\end{array}$ & $\begin{array}{c}\text { Paracatu } \\
\text { (Dietary restriction pasture) }\end{array}$ & Total \\
\hline Males & 367 & 4 & 1269 & - & 191 & 1831 \\
\hline Females & - & 8 & - & 406 & - & 414 \\
\hline$G 1 / G 1$ & - & $\begin{array}{c}2 \\
(16.6 \%)\end{array}$ & $\begin{array}{c}7 \\
(0.55 \%)\end{array}$ & $\begin{array}{c}4 \\
(0.98 \%)\end{array}$ & $\begin{array}{c}2 \\
(1 \%)\end{array}$ & (15) \\
\hline$G 1 / G 2$ & $\begin{array}{c}44 \\
(12 \%)\end{array}$ & $\begin{array}{c}5 \\
(41.6 \%)\end{array}$ & $\begin{array}{c}200 \\
(15.8 \%)\end{array}$ & $\begin{array}{c}56 \\
(13.8 \%)\end{array}$ & $\begin{array}{c}47 \\
(24.6 \%)\end{array}$ & (352) \\
\hline$G 2 / G 2$ & $\begin{array}{c}323 \\
(88 \%)\end{array}$ & $\begin{array}{c}5 \\
(41.6 \%)\end{array}$ & $\begin{array}{c}1062 \\
(83.7 \%)\end{array}$ & $\begin{array}{c}346 \\
(85.2 \%)\end{array}$ & $\begin{array}{c}142 \\
(74.3 \%)\end{array}$ & (1878) \\
\hline Total & 367 & 12 & 1269 & 406 & 191 & 2245 \\
\hline
\end{tabular}

In the feeding test at Jaraguari, MS, animals were pasture-fed and received water and mineral supplementation ad libitum, according to standard practices of the annual feeding test at the Perdizes Farm (Quilombo E\&P Ltda., Brazil). Pasture at Jaraguari was irrigated, so that green forage was available ad libitum all year long. Animals entered the feeding test at age 8-10 months and were sent to market 365 days later. Weight was adjusted to 550 days of age according to

$$
\mathrm{W} 550=[((\mathrm{AW} 365-\mathrm{BW}) / \mathrm{AEFT}) \times 550+\mathrm{BW}] \quad \text { (Equation 1) }
$$

with AW365 being actual weight, in kg, after the end of 365 days of feeding test; BW, birth weight, in $\mathrm{kg}$; AEFT, actual age, in days, at the end of the feeding test.

At the Sertãozinho Experimental Station, young bulls were fed silage ad libitum in the feedlot and heifers were exclusively pasture-fed; both bulls and heifers also had mineral mixture and water ad libitum. Young bulls in Paracatu were reared on a pasture diet, with mineral supplementation and water ad libitum. In order to produce full siblings of different genotypes 
at São Carlos, a G1/G2 heifer was mated to an unrelated $G 1 / G 2$ bull by means of current in vitro fertilization and embryo transfer protocols. Twelve full sibling heifers and bulls were pasture-reared with a supplementation of forage, silage and mineral mixture ad libitum. Measures of growth and carcass traits were obtained monthly.

\section{Statistical analyses}

Gene frequency, $\mathrm{x}_{\mathrm{i}}$, for the $\mathrm{i}$ allele, and genotypic frequency, $\mathrm{x}_{\mathrm{i} i}$, for the ii genotype were established for the population, according to

and

$$
\left.\mathrm{x}_{\mathrm{i}}=\left[\left(2 \mathrm{n}_{\mathrm{ii}}+\Sigma \mathrm{n}_{\mathrm{ij}}\right) / 2 \mathrm{n}\right] \quad \text { (Equation } 2\right)
$$

$$
\mathrm{x}_{\mathrm{ii}}=\left(\mathrm{n}_{\mathrm{ii}} / \mathrm{n}\right)
$$

where $n_{i \mathrm{i}}$ and $n_{\mathrm{ij}}$ refer to the number of homozygotes and heterozygotes observed for the $\mathrm{i}$ allele, respectively, and $\mathrm{n}$ refers to the number of individuals analyzed.

In the Sertãozinho experiments, growth traits were analyzed by the least squares method, using the GLM procedure of SAS ${ }^{\circledR}$ (Statistical Analysis System, SAS Institute Inc., Cary, NC, USA, 2000). To rule out possible confounding effects of selection response after 20 calf crops had undergone selection for weight gain in Sertãozinho herds, preliminary analyses were performed to define the model that best fitted the variation of the traits. Fixed effects of sex, month of birth, dam age, contemporary group (as defined by year of birth and herd), and genotypes that were significant $(\mathrm{P}<0.05)$ were maintained in the final model as $\mathrm{Y}_{\mathrm{ijklmn}}=\mu+$ $\mathrm{s}_{\mathrm{i}}+\mathrm{b}_{\mathrm{i}}+\mathrm{r}_{\mathrm{k}}+\mathrm{d}_{1}+\mathrm{c}_{\mathrm{m}}+\mathrm{g}_{\mathrm{n}}+\mathrm{e}_{\mathrm{ijklmn}}$, where $\mathrm{Y}=\mathrm{BW}$ and $\mathrm{W} 210$ for males and females; W378 and H378 for males; W550 and H550 for females; $\mu=$ general mean for each trait; $\mathrm{s}_{\mathrm{i}}=$ effect of sex of the animal (only for preweaning traits); $b_{j}=$ effect of year of birth of the animal $(j=$ $1991 \ldots$ 2003); $r_{k}$ = effect of month of birth of the animal; $k=8$ (August), 9 (September), 10 (October), and 11 (November); where $\mathrm{k}>11=11 ; \mathrm{d}_{1}=$ effect of dam age, in years $(1=3, \ldots, 11)$; $1>11=11 ; \mathrm{c}_{\mathrm{m}}=$ effect of the contemporary group; $\mathrm{g}_{\mathrm{n}}=$ genotype $(G 1 / G 1, G 1 / G 2, G 2 / G 2)$; $\mathrm{e}_{\mathrm{ijklmn}}=$ sample error, and BW = birth weight, in $\mathrm{kg} ; \mathrm{W} 210$ = weaning weight, in $\mathrm{kg}$, adjusted to 210 days of age; W378 and W550 = post-weaning weights, in kg, adjusted to 378 and 550 days of age for males and females, respectively; H378 and H550 = hip height, in cm, taken from the anterior portion of the sacrum bone to the ground, at the end of the pasture feeding test, adjusted to 378 and 550 days of age for males and females, respectively.

Also at Sertãozinho, the MTDFREML - Multiple Trait Derivative-Free Restricted Maximum Likelihood program (Boldman et al., 1995) was used to determine the growth trait contrasts between the $p G H$ genotypes. The pre-weaning traits were analyzed by means of a one-trait animal model, whereas bi-variate analyses were performed for post-weaning growth traits. The model also took into account fixed effects of sex, month of birth, dam age, contemporary group and genotype, in addition to the random genetic effect and permanent maternal (i.e., environmental) effect. In a preliminary analysis employing the likelihood ratio test, we found that this was the most appropriate model. To separate selection response from genotype effects, the model was run with a relationship matrix that included 1696 animals back to the seventh generation. Because of lack of pre-weaning and parental data from the Jaraguari, 
São Carlos and Paracatu experimental herds, growth traits associated with the different $p G H$ genotypes in the Jaraguari, São Carlos and Paracatu experiments were analyzed by Cohen's d effect size measure (Cohen, 1987), with differences checked for statistical significance with the Komolgorov-Smirnov test.

\section{RESULTS AND DISCUSSION}

A preliminary screening of our genotyping database from 6864 bovines of seven Bos indicus or tropically adapted Bos taurus breeds showed an increasing $G 1$ allele frequency from the Gyr breed to the Brahman breed (Figure 1). Brahman cattle, which are generally considered among the thriftiest cattle, had the highest $G 1$ allele frequency of all breeds that we studied, followed by Nelore. Because the Nelore breed is by far the most common beef breed in Brazil, we chose it as a model to better understand the effects of each $p G H$ allele on growth traits. However, the Nelore breed does not constitute a genetically homogeneous population - perhaps reflecting the diverse environmental realities in Brazil. In a genetic similarity study, we found that the Nelore population is divided into two genetically distinct populations, which we classified into the "thrifty type" and the "demanding type" (Dani et al., 2008). These observations provided insight for an analysis of the effects of the $G 1$ and $G 2$ alleles on post-weaning growth traits among Nelore cattle.

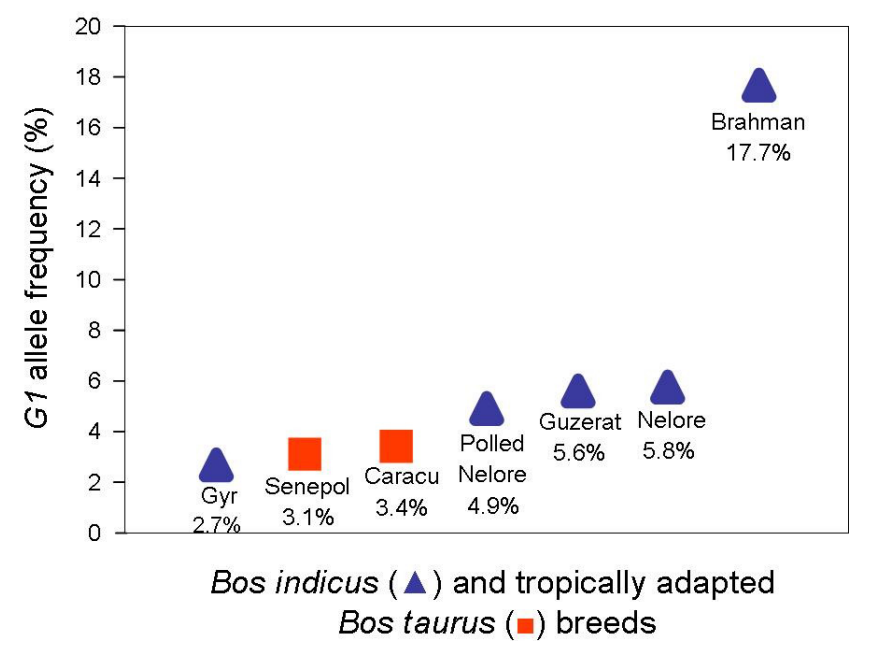

Figure 1. G1 allele frequencies in 6864 Bos indicus and tropically adapted Bos taurus breeds. $\mathrm{Gyr}(\mathrm{N}=576)$, Senepol $(\mathrm{N}=16)$, Caracu $(\mathrm{N}=312)$, Polled Nelore $(\mathrm{N}=467)$, Guzerat $(\mathrm{N}=331)$, Nelore $(\mathrm{N}=4781)$, Brahman $(\mathrm{N}=381)$.

The first indication that the $G 2$ allele could be associated with higher post-weaning growth as compared to the $G 1$ allele came in 2003 from our study on three experimental Nelore herds maintained at the Sertãozinho Experimental Station in São Paulo, Brazil (Lima, 2003). These three herds descended from a single herd (a control herd) that had undergone selection and differentiation for either average (one control herd) or increased post-weaning weight gain (two selection herds) (Razook, 1988; Razook et al., 1988, 2002). After 20 calf crops of these cattle had undergone selection pressure for increasing post-weaning weight gain, G2 
allele frequency had increased to near fixation values ( $\mathrm{f}=95 \%$ ) and the $G 1$ allele frequency had decreased from 12 to $5 \%$ in the two selection herds, when compared to the control herd.

These initial observations were followed by more detailed observations of Nelore cattle, reported here in a series of five feeding tests, including a full-sibling test. These tests were carried out at four different locations in Brazil (Sertãozinho, SP; São Carlos, SP; Jaraguari, MS, and Paracatu, MG) from 2003 to 2008, with 2245 animals of the Nelore breed: 1831 young bulls and 414 heifers. Overall frequencies of the $G 1$ and $G 2$ alleles in these experimental populations were 8.5 and $91.5 \%$, respectively. Total numbers of $G 1 / G 1, G 1 / G 2$ and G2/G2 animals were 15,352 and 1878 , respectively (Table 1).

At Sertãozinho, we compared growth traits of 367 young feedlot-fed bulls and 406 pasture-reared heifers. A mixed model was run to separate selection response from genotype effects, with a relationship matrix including 1696 animals back to the seventh generation. In this experiment, we were not able to observe any differences associated with different $p G H$ genotypes until 210 days of age, which was in line with evidence from other studies on the effects of $G H$ (Paz, 2002) and growth hormone receptor gene (GHR; Hale et al., 2000) variants on growth traits, indicating that the effects associated with genetic variants in the $G H / G H R$ axis are best noted after weaning. Significant genotype-associated differences in post-weaning growth traits, such as weight and hip height, were observed among the males in the feedlot regimen, but not among their female counterparts reared on a pasture diet (Figure 2 ). We hypothesized that distinct environmental sources had accounted for this variation. It was intriguing that the trend towards better performance of $G 2 / G 2$ that was observed in the more regular ad libitum feedlot feeding model, disappeared in the more exacting pasture feeding model.
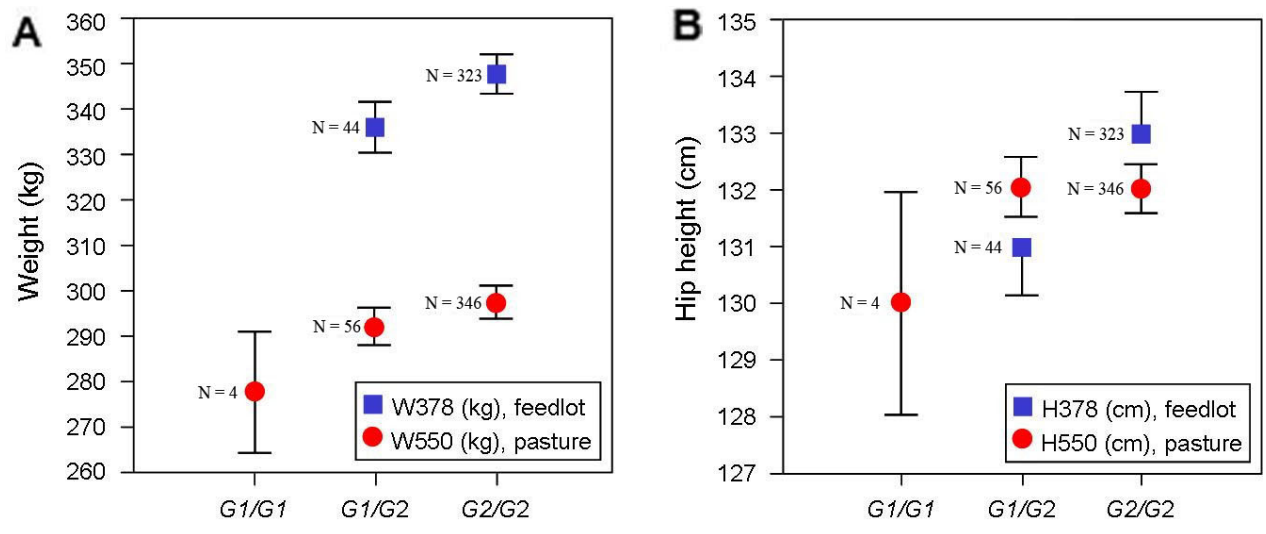

Figure 2. Environment as a source of variation. In Sertãozinho, significant genotype-associated differences in growth traits such as body weight (A) and hip height (B) were found among feedlot-fed Nelore bulls at 378 days of age (blue squares, W378 and H378, $\mathrm{N}=367$, means $\pm \mathrm{SD}$ ) but not among pasture-reared Nelore heifers at 550 days of age (red circles, W550 and H550, N = 406, means \pm SD). W378 and H378 contrasts (means \pm SE) between $G 1 / G 2$ and $G 2 / G 2$ bulls were $10.2 \pm 5.3 \mathrm{~kg}, \mathrm{P}=0.025$ and $2 \pm 0.6 \mathrm{~cm}, \mathrm{P}=0.001$, respectively.

A similar trend was observed in a comparison between the feeding tests carried out at São Carlos and Jaraguari. When there was ad libitum feeding under supplemented pasture conditions at São Carlos, homozygous $G 2 / G 2$, heifers averaged better in growth than their full sibling $G 1 / G 1$ or $G 1 / G 2$ counterparts, with differences being consistently observed from birth. 
However, under the less favorable, more exacting pasture feeding conditions at Jaraguari, the differences between the genotypes disappeared (Figure 3A). However, in our most exacting, DR model at Paracatu, the general drop in growth tended to be more accentuated for $G 2 /$ $G 2$ cattle than for $G 1 / G 2$ or $G 1 / G 1$ cattle. The $G 2 / G 2$ cattle performed similarly to $G 1 / G 2$ cattle in final body weight most of the time; however, as DR intensified, weight gain began to worsen at a higher rate for $G 2 / G 2$ cattle than for $G 1 / G 2$ or $G 1 / G 1$ cattle (Figure 3B). The worsening growth performance with increasing DR in three series of feeding tests followed a non-conservative pattern; i.e., $G 2 / G 2$ cattle were more affected by DR than $G 1 / G 2$ or $G 1 /$ $G 1$ cattle (Figure 3A,B). Accordingly, the decrease in the performance of $G 1 / G 1$ and $G 1 / G 2$ genotypes with increasing DR was more conservative, hinting at a greater resilience of $G 1 / X$ cattle (i.e., $G 1 / G 1$ and $G 1 / G 2$ cattle) in sustaining weight gain under DR. The average daily weight gain contrast between $G 1 / X$ and $G 2 / G 2$ cattle increased from $26 \mathrm{~g} /$ day in April, up to $52 \mathrm{~g} /$ day in June, meaning that the average relative weight gain; i.e., average daily weight gain as a function of body weight of $G 1 / X$ cattle, was $25 \%$ higher than that of $G 2 / G 2$ cattle (Figure 4). Notwithstanding the lower number of $G 1 / G 1$ cattle in this DR experiment, pairwise comparisons among genotypes yielded a reflection symmetry of $p G H$ allele substitution effects on body weight in the distinct dietary schemes, with higher differences being found in the comparisons between $G 1 / G 1$ and $G 2 / G 2$ cattle. These differences hint at i) an abiotropic rapid bodily decay effect of the $G 2$ allele under DR, as opposed to a resilient growth effect of the $G 1$ allele under DR and ii) symmetrically reflected disadvantageous effects of $G 1$ allele substitutions under ad libitum conditions (Figure 5).
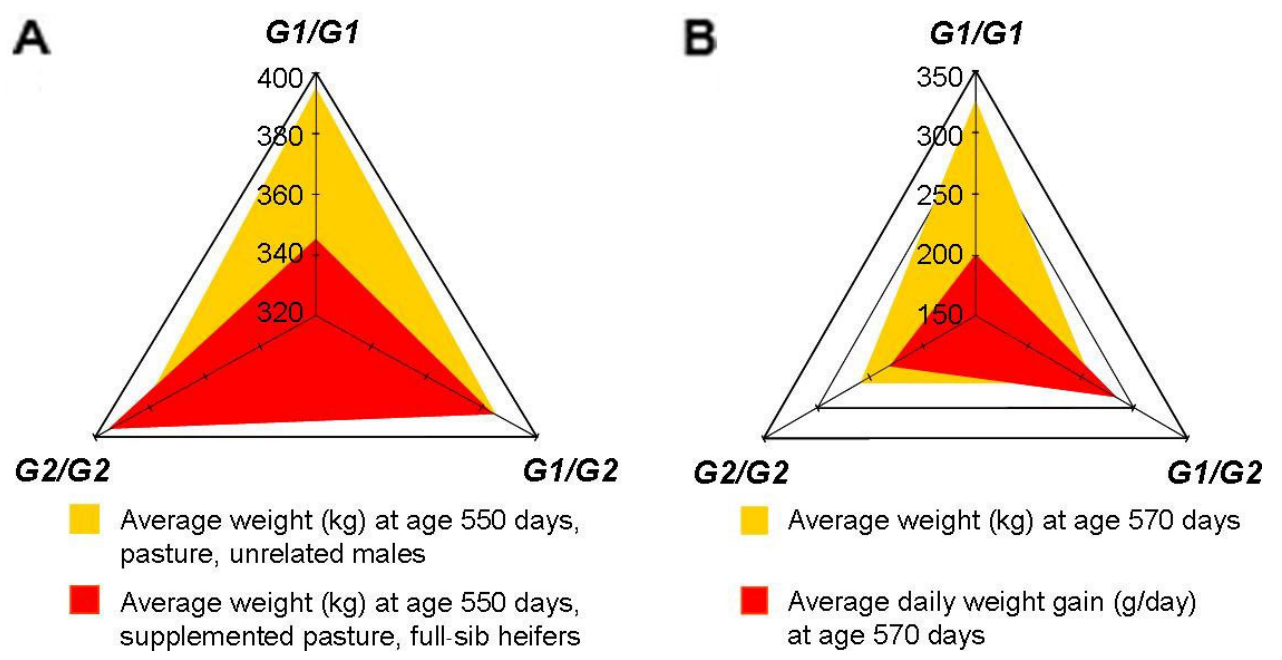

Figure 3. A shift to the thriftiest. Better weight gain performance of the $G 2 / G 2$ genotype is observed in the most favorable ad libitum supplemented pasture feeding model (A) (red triangle, eight full-sibling Nelore heifers at São Carlos). In a more exacting feeding model, the differences between genotypes disappeared [orange triangle in $A$, irrigated pasture feeding, 1269 unrelated Nelore bulls at Jaraguari]. In the most exacting dietary restriction (DR) model at Paracatu (B), G2/G2 Nelore cattle tended to perform even worse than $G 1 / G 2$ and $G 1 / G 1$ cattle in weight gain (red triangle) and weight at 570 days of age (orange triangle). The 191 Nelore bulls in this pasture feeding test were progressively subjected to DR as the drought season approached. DR is hinted at the lower average weights in $B$ as compared to $A$. 


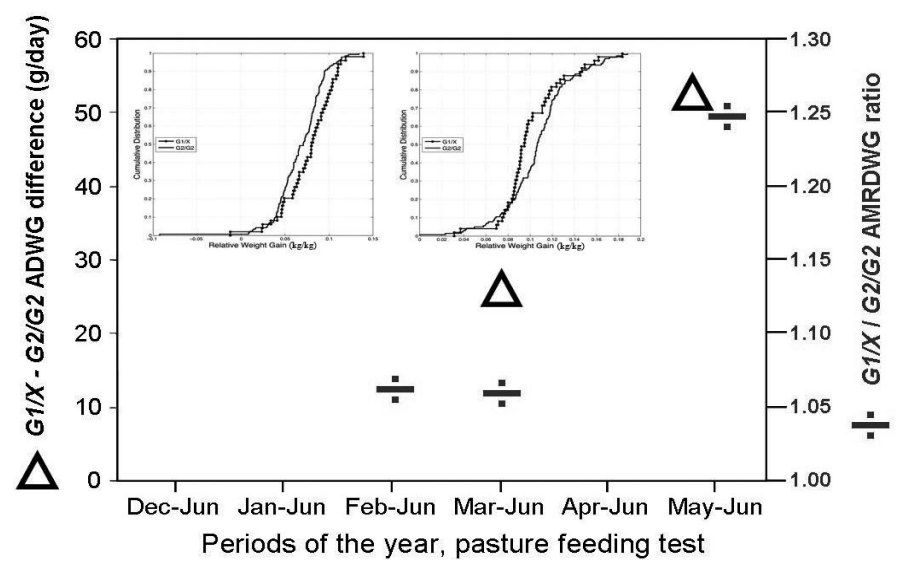

Figure 4. Increasing resilience with decreasing pasture. In the most exacting dietary restriction (DR) model at Paracatu, 191 young Nelore bulls ( $49 \mathrm{G} 1 / \mathrm{X}, 142 \mathrm{G} 2 / \mathrm{G} 2)$ were pasture fed from the middle of the rainy season to the middle of the drought season. The accumulated average daily weight gain (ADWG, left column) difference between $G 1 / X$ and $G 2 / G 2$ bulls increased from $26 \mathrm{~g}$ /day in March-April up to $52 \mathrm{~g} /$ day in May-June. Depicted are ADWG differences (triangles), which were significant at $\mathrm{P}<0.05$ in the Komolgorov-Smirnov test (K-S test). In May-June, accumulated mean relative daily weight gain (AMRDWG, right column) of $G 1 / X$ bulls was $25 \%$ higher than that of $G 2 / G 2$ bulls. Depicted are AMRDWG differences (division signs), which were significant at $\mathrm{P}<0.10$ in the K-S test. The insets show the switch in the K-S relative daily weight gain distribution pattern from a non-DR ( $G 2 / G 2$ curve above the $G 1 / X$ curve) to DR ( $G 2 / G 2$ below $G 1 / X$ curve).
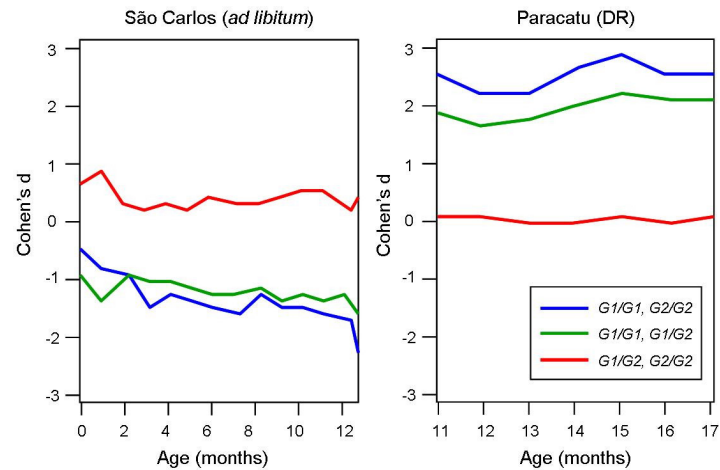

Figure 5. $p G H$ allele substitution effects on body weight are symmetrically reflected in different dietary schemes. Pairwise body weight differences associated with different $p G H$ genotypes changed symmetrically from São Carlos (ad libitum pasture/feedlot feeding) to Paracatu (dietary restriction (DR), pasture). These changes are reflected in the magnitude and direction of the differences, as measured by Cohen's d effect size measure. G2/ $G 2$ and $G 1 / G 2$ animals performed better than $G 1 / G 1$ under ad libitum conditions, but under DR the relative performance was inverted. Higher differences were found in the comparisons between homozygous $G 1 / G 1$ and $G 2 / G 2$. The number of $G 1 / G 1, G 1 / G 2$ and $G 2 / G 2$ Nelore animals were, respectively, 2, 5 and 5 in São Carlos and 2, 47 and 142 in Paracatu. Statistical analysis was conducted by a one-tailed Komolgorov-Smirnov test. Differences between $G 1 / G 1$ and $G 2 / G 2$, in the Paracatu group, were significant ( $\mathrm{P}=0.0075)$; differences between $G 1 / G 1$ and $G 1 / G 2$ were significant $(\mathrm{P}=0.025)$; differences between $G 1 / G 2$ and $G 2 / G 2$ in Paracatu were not significant, and Cohen's d was very small in this comparison. An analogous significance analysis could not be conducted for the São Carlos group due to the very small sample size, and only size effects are reported. There was an after birth weight adjustment of $G 1 / G 1$ siblings, which were born to $G 2 / G 2$ surrogate mothers, hinting at a possible loss of maternal effect during the first two months of life. 
The conclusion we can draw from the feeding test results reported here is that under more favorable, ad libitum feeding conditions, homozygous $G 2 / G 2$ cattle perform better than $G 1 / G 1$ cattle (or $G 1 / G 2$ cattle, to a lesser extent) in post-weaning growth traits. This explains why the $G 2$ allele was nearly fixed in the ad libitum fed population. Under more exacting DR conditions, however, $G 1 / G 1$ cattle (and $G 1 / G 2$ cattle, to a lesser extent) performed better in post-weaning growth or, more to the point, they were more resilient to DR-related decreases in growth rates than their $G 2 / G 2$ counterparts. Under DR, two $G 1$ alleles provided maximal adaptation, exhibited as growth resilience and thriftiness, while one or two $G 2$ alleles were detrimental or abiotropic. These differences may be a consequence of allele substitution effects on fine-tuned regulatory transcriptional dynamics at the $p G H$ site. As a result of these dynamics, homozygous $G 1$ cattle are expected to be favored in the most exacting DR selection schemes, with a resulting increase in reproductive advantage of the $G 1$ allele, while, in less exacting situations, both homozygous $G 1 / G 1$ and heterozygous $G 1 / G 2$ cattle would be favored. Under more favorable conditions, both $G 1 / G 2$ and $G 2 / G 2$ would be favored over $G 1 / G 1$, which would result in genetic polymorphism still being maintained in the population.

Whereas it appears plausible that the superior performance of cattle carrying the $G 2$ allele is the reason for the fixation of this allele in some domesticated Bos taurus cattle reared under nutrient-surplus conditions, it appears equally plausible that the thrifty nature of the G1 allele is the reason for its conservation in some thrifty Bos indicus cattle breeds, such as Brahman, Nelore and Guzerat, reared under more exacting environments. There is no reason to believe that either of these alleles will promote better adaptation, extended life span or increased longevity (in the sense of age-specific fitness, resilience or resistance to failure) by themselves; on the contrary, there is every reason to believe that each of these alleles will promote these life-promoting tasks within a range of nutritionally distinct environments when they are selected for. In other words, there can be no certainty about which nutritional scheme is better until we know exactly how different nutritional adaptations are inherited.

This argumentation has a bearing on the general presumption that DR works by increasing life span and longevity. Our results suggest that DR may even be detrimental to $G 2$ cattle, while DR may be better tolerated by $G 1$ cattle. Therefore, it may be a fallacy to assume that DR itself works to increase lifespan and longevity, without understanding the genetic structure of the population under DR. It should not be forgotten that lifespan and longevity under different dietary regimens are just as much consequences of selection as their causes. In other words, we should not speculate about ideal nutritional schemes without knowing the genetic make-up of the individual or population and the environment in which this genetic make-up evolved.

A gene can be maintained or lost in a population as a function of random drift, associated with small population size, or due to the gene's ability or inability to confer adaptive advantage, in other words, the "fitness value" of the gene. Adaptive advantage obviously depends on the environment, meaning, both in the case of domesticated cattle and of people, not only the natural environment but also - which is less obvious - the man-made environment. This is illustrated by the divergence in North Eurasian cattle breeds, which involves polymorphisms in genes of the somatotropic axis, more than neutral microsatellite polymorphisms ( $\mathrm{Li}$ et al., 2006), indicating a role of man-guided selection in enhancing production traits.

However, even over 10,000 years of multiple domestication events (Loftus et al., 1994; Troy et al., 2001; Hanotte et al., 2002; Bruford et al., 2003) have not been sufficient to remove the ancient, wild-type $G 1$ allele from some bovine populations. Our study recapitulates what 
might have happened during evolution and during domestication of cattle; we suggest that the G1 allele was maintained in those cattle populations because it confers a "thrifty phenotype", which would have been advantageous in exacting environmental conditions, such as those accompanying drought, overgrazing and desertification in some regions of the world.

It is a happy circumstance that Brahman cattle, which is the breed showing the highest $G 1$ allele frequency (Figure 1), are distinguished among all Bos indicus cattle for their "thrifty phenotype". This phenotype has been generally recognized as the outstanding feature of these cattle, a feature that has been translated by Brahman breeders as environmental adaptivity, longevity, ability to survive and thrive where other types have failed, hardiness and ability to produce on marginal lands (ABBA, 2009). These are also known attributes of the "thrifty Nelore type", and the Guzerat breed, which is genetically similar to the Brahman (Dani et al., 2008).

Thrifty cattle and thrifty genes have a lot to teach us about the past, the present and the prospects for the future. We are taught to believe that crop and animal breeders and geneticists alike carry a great deal of responsibility for feeding mankind today and in the future. Most people like to think about this responsibility as meaning that scientists and breeders have to continually devise new technologies, varieties or breeds with ever increasing production traits. It seems as if we hungry humans are improving on our own right, making our animals and plants in our own image and resemblance. However, in the real world of increasing population and shrinking resources, only decreases in the production and consumption of food will lead to a reduction in our socio-environmental impacts (Diamond, 2002).

We must then begin to think more seriously about this profound truth; when it comes to limited resources, it is "survival of the thriftiest".

\section{ACKNOWLEDGMENTS}

Research supported by Excegen Genética S.A., Genon Genética Ltda., and grants from FAPESP (Genon, S.U. Dani, E. Monteiro, F.B. Knackfuss), SEBRAE-MG (Excegen), FAPEMIG (Excegen, S.U. Dani, M.A.C. Dani) and CNPq (S.U. Dani, M.A.C. Dani), Brazil. We thank co-workers at Excegen, C. Trancoso, D.V. Arruda, and L.M. Souza for laboratory assistance; F.S. Teles, S. Campos and A.F. Campos for assistance in setting up the data bank; P. Jardim and J.L.F. Spelta for secretarial assistance; J.H. Rabelo for field assistance; E.K. Pedroso for help establishing a collaboration with Quilombo E. \& P. Ltda. and A.S. Ferreira in the Jaraguari feeding experiment; co-workers at the Jaraguari, Sertãozinho, São Carlos and Paracatu locations, M.A. Marchezini, L.A. Figueiredo, F. Gomes de Castro Jr., M. Mauad Neto, O.S. da Silva Filho, Brascan Cattle S.A., Beckhauser Troncos e Balanças, Bellman Nutrição Animal and Fundação Acangaú for field assistance and support. The following patents by Excegen Genética S.A. relate to the subject of this study: PI 0403770-7 A (2006) and PI 0503427-2 (2007), INPI, Brazil.

\section{REFERENCES}

ABBA (2009). American Brahman Breeders Association. Available at [http://www.brahman.org/brahmaninformation. html]. Accessed August 10, 2009.

Berryman DE, Christiansen JS, Johannsson G, Thorner MO, et al. (2008). Role of the GH/IGF-1 axis in lifespan and healthspan: lessons from animal models. Growth Horm. IGF Res. 18: 455-471. 
Boldman KG, Kriese LA, Vleck LD, van Tassel CP, et al. (1995). A Manual for Use of MTDFREML: a Set of Programs to Obtain Estimates of Variances and Covariances (DRAF). Department of Agriculture/Agricultural Research Service, Lincoln.

Bruford MW, Bradley DG and Luikart G (2003). DNA markers reveal the complexity of livestock domestication. Nat. Rev. Genet. 4: 900-910.

Butler ST, Marr AL, Pelton SH, Radcliff RP, et al. (2003). Insulin restores GH responsiveness during lactation-induced negative energy balance in dairy cattle: effects on expression of IGF-I and GH receptor 1A. J. Endocrinol. 176: 205-217.

Cohen J (1987). Statistical Power Analysis for the Behavioral Sciences. Erlbaum, Hillsdale.

Dani MA, Heinneman MB and Dani SU (2008). Brazilian Nelore cattle: a melting pot unfolded by molecular genetics. Genet. Mol. Res. 7: 1127-1137.

DeNise S and Personal Communication cited in Regitano LCA (1996). Polimorfismo molecular em gerações de bovinos da raça Canchim. DSc dissertation, Escola Superior de Agricultura Luiz de Queiróz, Universidade de São Paulo, Piracicaba.

Diamond J (2002). Evolution, consequences and future of plant and animal domestication. Nature 418: 700-707.

Ge W, Davis ME, Hines HC, Irvin KM, et al. (2003). Association of single nucleotide polymorphisms in the growth hormone and growth hormone receptor genes with blood serum insulin-like growth factor I concentration and growth traits in Angus cattle. J. Anim. Sci. 81: 641-648.

Gordon DF, Quick DP, Erwin CR, Donelson JE, et al. (1983). Nucleotide sequence of the bovine growth hormone chromosomal gene. Mol. Cell Endocrinol. 33: 81-95.

Grochowska R, Sorensen P, Zwierzchowski L, Snochowski M, et al. (2001). Genetic variation in stimulated GH release and in IGF-I of young dairy cattle and their associations with the leucine/valine polymorphism in the GH gene. $J$. Anim. Sci. 79: 470-476.

Hale CS, Herring WO, Shibuya H, Lucy MC, et al. (2000). Decreased growth in Angus steers with a short TG-microsatellite allele in the P1 promoter of the growth hormone receptor gene. J. Anim. Sci. 78: 2099-2104.

Hanotte O, Bradley DG, Ochieng JW, Verjee Y, et al. (2002). African pastoralism: genetic imprints of origins and migrations. Science 296: 336-339.

Katoh K, Kouno S, Okazaki A, Suzuki K, et al. (2008). Interaction of GH polymorphism with body weight and endocrine functions in Japanese black calves. Domest. Anim. Endocrinol. 34: 25-30.

Lee BK, Lin GF, Crooker BA, Murtaugh MP, et al. (1996). Association of somatotropin (BST) gene polymorphism at the 5th exon with selection for milk yield in Holstein cows. Domest. Anim. Endocrinol. 13: 373-381.

Li MH, Adamowicz T, Switonski M, Ammosov I, et al. (2006). Analysis of population differentiation in North Eurasian cattle (Bos taurus) using single nucleotide polymorphisms in three genes associated with production traits. Anim. Genet. 37: 390-392.

Lima S (2003). Estudo de um Polimorfismo na Região Promotora do Hormônio de Crescimento Bovino (bGH) em Rebanhos Nelore Selecionados para Peso Pós Desmama. Masters of Science thesis, UNESP, Jaboticabal.

Loftus RT, MacHugh DE, Bradley DG, Sharp PM, et al. (1994). Evidence for two independent domestications of cattle. Proc. Natl. Acad. Sci U. S. A. 91: 2757-2761.

Lucy MC, Hauser S, Eppard P, Krivi G, et al. (1991). Genetic polymorphism within the bovine somatotropin (bST) gene detected by polymerase chain reaction and endonuclease digestion. J. Dairy Sci. 74 (Suppl 1): 284.

MacEachern S, McEwan J and Goddard M (2009). Phylogenetic reconstruction and the identification of ancient polymorphism in the Bovini tribe (Bovidae, Bovinae). BMC Genomics 10: 177.

Mitra A, Schlee P, Balakrishnan C and Pirchner F (1995). Polymorphism at growth-hormone and prolactin loci in Indian cattle and buffalo. J. Anim. Breed. Genet. 11: 771-774.

Paz C (2002). Associação entre Polimorfismos Genéticos e Parâmetros da Curva de Crescimento em Bovinos de Corte. DSc dissertation, Escola Superior de Agricultura Luiz de Queiróz, Universidade de São Paulo, Piracicaba.

Radcliff RP, McCormack BL, Keisler DH, Crooker BA, et al. (2006). Partial feed restriction decreases growth hormone receptor 1A mRNA expression in postpartum dairy cows. J. Dairy Sci. 89: 611-619.

Razook AG (1988). Seleção para Peso Pós-Desmama em Bovinos Nelore e Guzerá: Intensidade de Seleção e Respostas Direta e Correlacionadas. Ph.D. thesis, Universidade de São Paulo, Ribeirão Preto.

Razook AG, Bonilha Neto L and Figueiredo L (1988). Seleção para peso pós-desmama em bovinos Nelore e Guzerá. I. Diferenciais e intensidades de seleção. Bol. Ind. Anim. 45: 241-271.

Razook AG, Figueiredo LA, Bonilha Neto LM, Cyrillo JNSG, et al. (2002). The role of the Experimental Station of Sertãozinho (SP) - Brazil in the preservation and selection of Zebu breeds and Caracu. CD-ROM 1, 68. In: Proceedings of the 7th World Congress on Genetics Applied to Livestock Production, Montpellier. 
Ritz LR, Glowatzki-Mullis ML, MacHugh DE and Gaillard C (2000). Phylogenetic analysis of the tribe Bovini using microsatellites. Anim. Genet. 31: 178-185.

Rodrigues CV, Guimaraes SE, Dias NE and Pinheiro LE (1998). Identification of a novel polymorphism in the promoter region of the bovine growth hormone gene. Anim. Genet. 29: 65-66.

Rodrigues CV, Neto ED and Pinheiro LEL (1999). A variation of simple repeat sequence in the promoter region of the bovine growth hormone (bGH) gene in beef cattle is similar to water buffalo. J. Anim. Breed. Genet. 116: 15-19.

Rosa A (1997). Caracterização da Raça Nelore e Teste de Paternidade por Marcadores Moleculares. MSc dissertation, Escola Superior de Agricultura Luiz de Queiroz, Universidade de São Paulo, Piracicaba.

Sanguinetti CJ, Dias NE and Simpson AJ (1994). Rapid silver staining and recovery of PCR products separated on polyacrylamide gels. Biotechniques 17: 914-921.

Schlee P, Graml R and Rottmann O (1994). Influence of growth hormone genotypes on breeding values of Simmental bulls. J. Anim. Breed. Genet. 111: 253-256.

Shimokawa I, Higami Y, Tsuchiya T, Otani H, et al. (2003). Life span extension by reduction of the growth hormoneinsulin-like growth factor-1 axis: relation to caloric restriction. FASEB J. 17: 1108-1109.

Smith JM, Van Amburgh ME, Diaz MC, Lucy MC, et al. (2002). Effect of nutrient intake on the development of the somatotropic axis and its responsiveness to GH in Holstein bull calves. J. Anim. Sci. 80: 1528-1537.

Sorensen P, Grochowska R, Holm L, Henryon M, et al. (2002). Polymorphism in the bovine growth hormone gene affects endocrine release in dairy calves. J. Dairy Sci. 85: 1887-1893.

Troy CS, MacHugh DE, Bailey JF, Magee DA, et al. (2001). Genetic evidence for Near-Eastern origins of European cattle. Nature 410: 1088-1091.

Zha Y, Taguchi T, Nazneen A, Shimokawa I, et al. (2008). Genetic suppression of GH-IGF-1 activity, combined with lifelong caloric restriction, prevents age-related renal damage and prolongs the life span in rats. Am. J. Nephrol. 28: 755-764. 